\title{
Development of small scale frustum cone shaped butter churn
}

\author{
ADARSH M. KALLA, C. SAHU, A.K. AGRAWAL, A. KHARE, K.K. CHOUDHAURY, A. SHRIVASTAVA AND GEETESH SINHA
}

\begin{abstract}
A novel small scale improved butter making unit called 'Frustum Cone Shaped Butter Churn was developed with working capacity of 5 liter curd/batch. This paper deals with development of parts of churn i.e. inner and outer frustum cone, stirring tube, head and closure and insulation etc. For better insulation foamed polyethylene was used to offset the effect of ambient on temperature of curd filled inside the churn. For controlling the speed of the motor, gear and pulley arrangement with v-belt was used. The highest overrun and yield of butter were recorded to be 24.41 per cent and $1.63 \mathrm{~kg} / 5 \mathrm{l}$. curd at higher churning temperature of $12^{\circ} \mathrm{C}$ and higher churn speed of $85 \mathrm{rpm}$. However, the optimum speed of churn for good quality butter production was found to be $60 \mathrm{rpm}$ at churning temperature of $10^{\circ} \mathrm{C}$.
\end{abstract}

KEY WORDS : Belt-pulley, Butter, Curd, Churn, Foamed polyethylene, Frustum cone shaped butter churn

How TO CITE THIS PAPER : Kalla, Adarsh M., Sahu, C., Agrawal, A.K., Khare, A., Choudhaury, K.K., Shrivastava, A. and Sinha, Geetesh (2015). Development of small scale frustum cone shaped butter churn. Res. J. Animal Hus. \& Dairy Sci., 6(2) : 153-157.

\section{MEMBERS OF RESEARCH FORUM}

Address for correspondence :

Geetesh Sinha, Department of Dairy Engineering, College of Dairy Science and

Food Technology, RAIPUR (C.G.) INDIA

Email : geeteshsinha20@gmail.com

Associated Authors':

Adarsh M. Kalla, C. Sahu, A.K. Agrawal, A. Khare, K.K. Choudhaury and

A. Shrivastava, Department of Dairy Engineering, College of Dairy Science and Food Technology, RAIPUR (C.G.) INDIA 